\title{
Phenotypic Correlations among Agronomic Traits in Olive Progenies
}

\author{
Lorenzo León' 1 \\ Departamento de Agronomía, E.T.S.I.A.M., Universidad de Córdoba, Avda. Menéndez Pidal s/n, 14080 \\ Córdoba, Spain \\ Luis M. Martín \\ Departamento de Genética, E.T.S.I.A.M., Universidad de Córdoba, Avda. Menéndez Pidal s/n, 14080 \\ Córdoba, Spain \\ Luis Rallo \\ Departamento de Agronomía, E.T.S.I.A.M., Universidad de Córdoba, Avda. Menéndez Pidal s/n, 14080 \\ Córdoba, Spain
}

ADDITIONAL INDEX WORDs. fatty acids, fruit characters, Olea europaea, olive breeding, principal components analysis, seedlings

\begin{abstract}
Aвstract. Thirteen characters were evaluated over four years in progenies from a diallel cross among the olive (Olea europaea L.) cultivars 'Arbequina', 'Frantoio', and 'Picual' to determine if phenotypic correlations existed between these characters. Yield per tree, ripening date, oil yield components and fatty acid composition were recorded annually once seedlings began to flower and produce fruit. Significant correlations were found between several characters including oil yield components and fatty acids composition. Lower correlation coefficients were obtained between ripening date and oil and oleic acid content. Generally, yield was not correlated with the other characters evaluated. Principal components analysis confirmed the main correlations among characters and showed them to be independent of the parents used.
\end{abstract}

Fruit breeding programs require a good knowledge of the agronomic traits to improve, including the relationships among them, since selection for one character will result in progress for positively correlated traits but regress for negatively correlated traits (Scossirolly et al., 1963). Understanding the correlations among characters might also allow indirect selection for mature crop traits during the juvenile period (Visser, 1976; Zimmerman, 1977). A long juvenile period is a major hindrance in olive breeding since fruit characters can only be evaluated once flowering and fruiting have been established (Lavee et al., 1996; SantosAntunes et al., 1999). The knowledge of high correlations among characters could also allow the improvement of several traits by selecting only one, thus reducing the number of traits to be measured (Hansche et al., 1972).

Studies of correlation between different characters in olive (Olea europaea L.) have usually been carried out in cultivars collections and rarely in progenies from crosses. The objective of these studies was to determine the correlations among several fruit characters (Fanizza, 1982; Fontanazza et al., 1999), among oil yield components (Sánchez-Gómez and Fernández-Díez, 1991) or fatty acids composition (Tous and Romero, 1993). However, none of these works have provided an overall view by either evaluating a large number of individuals or analyzing a large number of characteristics.

The objective of this work was to determine if phenotypic correlations existed among some agronomic traits in olive progenies,

Received for publication 2 Dec. 2002. Accepted for publication 5 May 2003. This research was supported by grant INIACAO97-001-C12-11 and CAO00-018-C7-2 of the Spanish Ministry of Agriculture, Food and Fisheries. Thanks are due to Pilar Rallo and Angjelina Belaj for their valuable suggestions and Gerard Downey from the National Food Centre (Dublin, Ireland) for statistical assistance. We also acknowledge the CIFA "Alameda del Obispo" in Córdoba and CIFA "Venta del Llano" in Mengíbar (Jaén) for the facilities created.

'To whom reprint requests should be addressed; e-mail ag2lemol@uco.es. and consequently improve the efficiency of the olive breeding program being carried out in Cordoba since 1992.

\section{Materials and Methods}

Plant material. Seedlings from a diallel cross (nine combinations) among 'Arbequina', 'Frantoio' and 'Picual' cultivars were used in this study. Parents were chosen based on differences in geographical origin ('Arbequina' from Catalonia, northeast Spain; 'Frantoio' from Tuscany, central Italy; and 'Picual' from Andalusia, south Spain), earliness of bearing and fatty acids composition. All three cultivars show good productivity with high oil content and quality. Seedlings (342) from crosses made in Spring 1992 were planted in open field in April 1994, after a period of forced growth in a greenhouse during 1993. A second and third planting of 214 and 192 seedlings from crosses made in 1993 and 1994 was done in February 1995 and March and June 1996, respectively. In total, 748 seedlings were evaluated each year from 1996 to 1999.

Table 1. Characters evaluated with number of observations by year and planting date.

\begin{tabular}{lccc}
\hline Group & $\begin{array}{c}\text { Yield and } \\
\text { ripening date }\end{array}$ & $\begin{array}{c}\text { Oil yield } \\
\text { components }\end{array}$ & $\begin{array}{c}\text { Fatty acids } \\
\text { composition }\end{array}$ \\
\hline Year & & & \\
1996 & 206 & 125 & 159 \\
1997 & 328 & 225 & 288 \\
1998 & 592 & 547 & --- \\
1999 & 319 & 293 & --- \\
$\quad$ Total & 1445 & 1190 & 447 \\
Plantation date & & & \\
April 1994 & 659 & 527 & 299 \\
February 1995 & 497 & 425 & 134 \\
March-June 1996 & 289 & 238 & 14 \\
Total & 1445 & 1190 & 447 \\
\hline
\end{tabular}


Characters evaluated. Fruit were harvested at the same ripeness using a color measurement index of the fruit maturity according to a scale from 0 to 7 (Frías et al., 1991). Samples were collected for analysis when enough fruit corresponding to the category 4 (black skin and white flesh) were available. Ripening date, expressed as days after 1 Sept., and total yield per tree were recorded. Three samples of 50 fruit each were prepared to obtain data on oil yield components. Average fruit weight was determined and, after removing and cleaning the stones, flesh and stone weights were also recorded. Flesh samples were dried in a forced-air oven at $105{ }^{\circ} \mathrm{C}$ for $42 \mathrm{~h}$ to dehydrate samples (Del Río and Romero, 1999). The oil percentage of dried samples was recorded in an NMR analyzer. From these determinations, the flesh to stone ratio (both in fresh and dry weight basis) and the fruit oil content on a dry weight basis were calculated. Fatty acids methyl esters (FAMEs) were prepared following the procedure of Garcés and Mancha (1993) and separated using a flame ionization detector gas chromatograph equipped with a BPX-70 column (50 m, 0.25 $\mathrm{mm}$ I.D., $0.22 \mathrm{~mm}$ film thickness). Frozen samples were stored for this purpose and 10 replications per genotype were analyzed. Oil yield components and fatty acids composition could not be evaluated in all seedlings since a minimum amount of fruit was required for these evaluations (Table 1).

Data ANALYSIS. Pearson's correlation coefficient was calculated among all the traits for each year using the statistical package Statistix (analytical software). The 13 characteristics evaluated

Table 2. Correlation coefficients between characters by year (Values obtained in 1996, 1997, 1998 and 1999 are indicated from top to bottom). Significant correlations at $P<0.01$ are indicated in bold.

\begin{tabular}{|c|c|c|c|c|c|c|c|c|c|c|c|c|}
\hline & $\begin{array}{l}\text { Ripening } \\
\text { date } \\
\text { (d.a.1 Sept.) }\end{array}$ & $\begin{array}{l}\text { Fruit } \\
\text { fresh } \\
\text { wt }(g)\end{array}$ & $\begin{array}{c}\text { Flesh } \\
\text { moisture } \\
(\%)\end{array}$ & $\begin{array}{c}\text { Flesh to } \\
\text { stone ratio } \\
\text { (fresh wt basis }\end{array}$ & $\begin{array}{l}\text { Flesh to } \\
\text { stone ratio } \\
\text { (dry wt basi }\end{array}$ & $\begin{array}{l}\text { Oil content } \\
\text { [flesh dry wt } \\
\text { is)basis }(\%)]\end{array}$ & $\begin{array}{l}\text { Oil content } \\
\text { [fruit dry wt } \\
\text { basis }(\%)]\end{array}$ & $\begin{array}{c}\text { Palmitic } \\
\text { acid } \\
(\%)\end{array}$ & $\begin{array}{c}\text { Palmitoleic } \\
\text { acid } \\
(\%)\end{array}$ & $\begin{array}{c}\text { Stearic } \\
\text { acid } \\
(\%)\end{array}$ & $\begin{array}{l}\text { Oleic } \\
\text { acid } \\
(\%)\end{array}$ & $\begin{array}{c}\text { Linoleic } \\
\text { acid } \\
(\%)\end{array}$ \\
\hline \multirow[t]{4}{*}{ Yield per tree $(\mathrm{kg})$} & 0.47 & -0.08 & -0.18 & 0.06 & 0.16 & 0.25 & 0.24 & -0.20 & -0.07 & -0.07 & 0.18 & -0.12 \\
\hline & 0.12 & -0.12 & -0.06 & -0.01 & 0.05 & 0.05 & 0.05 & -0.04 & 0.01 & -0.12 & 0.11 & -0.12 \\
\hline & 0.10 & -0.36 & -0.04 & -0.28 & -0.31 & -0.24 & -0.32 & --- & --- & --- & --- & --- \\
\hline & 0.32 & -0.28 & -0.28 & -0.27 & -0.06 & -0.01 & -0.03 & --- & --- & --- & --- & --- \\
\hline \multirow[t]{4}{*}{ Ripening date (d.a.1 Sep) } & $x$ & -0.12 & -0.20 & -0.01 & 0.12 & 0.39 & 0.28 & -0.41 & -0.29 & -0.05 & 0.38 & -0.25 \\
\hline & & -0.05 & -0.07 & -0.19 & -0.12 & 0.15 & 0.03 & -0.40 & -0.27 & -0.02 & 0.46 & -0.44 \\
\hline & & -0.28 & -0.63 & -0.30 & 0.20 & 0.21 & 0.22 & --- & --- & --- & --- & --- \\
\hline & & -0.39 & -0.58 & -0.34 & 0.09 & 0.29 & 0.23 & --- & --- & --- & --- & --- \\
\hline \multirow{4}{*}{\multicolumn{2}{|c|}{ Fruit fresh weight (g) }} & $x$ & 0.11 & 0.32 & 0.18 & 0.02 & 0.10 & 0.17 & 0.07 & 0.11 & -0.21 & 0.20 \\
\hline & & & 0.03 & 0.28 & 0.20 & 0.16 & 0.19 & 0.11 & 0.06 & 0.15 & -0.17 & 0.18 \\
\hline & & & 0.31 & 0.58 & 0.31 & 0.20 & 0.29 & --- & --- & --- & --- & --- \\
\hline & & & 0.46 & 0.49 & 0.10 & -0.04 & 0.02 & --- & --- & --- & --- & --- \\
\hline \multirow{4}{*}{\multicolumn{2}{|c|}{ Flesh moisture (\%) }} & & $x$ & 0.10 & -0.58 & -0.59 & -0.69 & 0.27 & 0.48 & 0.07 & -0.20 & 0.01 \\
\hline & & & & 0.04 & -0.63 & -0.65 & -0.70 & 0.33 & 0.30 & -0.11 & -0.25 & 0.17 \\
\hline & & & & 0.42 & -0.39 & -0.48 & -0.49 & --- & --- & --- & --- & --- \\
\hline & & & & 0.45 & -0.38 & -0.59 & -0.57 & --- & --- & --- & --- & --- \\
\hline \multirow{4}{*}{\multicolumn{2}{|c|}{ Flesh to stone ratio(fresh weight basis) }} & & & $x$ & 0.72 & 0.17 & 0.49 & 0.07 & -0.08 & 0.04 & -0.02 & 0.06 \\
\hline & & & & & 0.72 & 0.31 & 0.54 & 0.10 & 0.01 & 0.04 & -0.11 & 0.14 \\
\hline & & & & & 0.63 & 0.22 & 0.47 & --- & --- & --- & --- & --- \\
\hline & & & & & 0.61 & 0.06 & 0.33 & --- & --- & --- & --- & --- \\
\hline \multirow{4}{*}{\multicolumn{2}{|c|}{ Flesh to stone ratio (dry weight basis) }} & & & & $x$ & 0.53 & 0.87 & -0.14 & -0.38 & -0.03 & 0.12 & 0.05 \\
\hline & & & & & & 0.67 & 0.88 & -0.06 & -0.19 & 0.09 & 0.06 & 0.10 \\
\hline & & & & & & 0.62 & 0.89 & --- & --- & --- & --- & --- \\
\hline & & & & & & 0.57 & 0.84 & --- & --- & --- & --- & --- \\
\hline \multirow{4}{*}{\multicolumn{2}{|c|}{ Oil content [flesh dry weight basis $(\%)$ ] }} & & & & & $x$ & 0.86 & -0.32 & -0.33 & 0.14 & 0.29 & -0.18 \\
\hline & & & & & & & 0.93 & -0.29 & -0.33 & 0.15 & 0.35 & -0.27 \\
\hline & & & & & & & 0.90 & --- & --- & --- & --- & --- \\
\hline & & & & & & & 0.92 & --- & --- & --- & --- & --- \\
\hline \multirow{4}{*}{\multicolumn{2}{|c|}{ Oil content [fruit dry weight basis $(\%)$ ] }} & & & & & & $x$ & -0.25 & -0.41 & 0.02 & 0.23 & -0.07 \\
\hline & & & & & & & & -0.21 & -0.29 & 0.14 & 0.25 & -0.16 \\
\hline & & & & & & & & --- & --- & --- & --- & --- \\
\hline & & & & & & & & --- & --- & --- & --- & --- \\
\hline \multirow[t]{4}{*}{ Palmitic acid $(\%)$} & & & & & & & & $x$ & 0.74 & -0.04 & -0.83 & 0.57 \\
\hline & & & & & & & & & 0.67 & -0.09 & -0.87 & 0.71 \\
\hline & & & & & & & & & --- & --- & --- & --- \\
\hline & & & & & & & & & --- & --- & --- & --- \\
\hline \multirow[t]{4}{*}{ Palmitoleic acid (\%) } & & & & & & & & & $\times$ & -0.12 & -0.53 & 0.20 \\
\hline & & & & & & & & & & -0.20 & -0.51 & 0.29 \\
\hline & & & & & & & & & & --- & --- & --- \\
\hline & & & & & & & & & & --- & --- & --- \\
\hline \multirow[t]{4}{*}{ Stearic acid (\%) } & & & & & & & & & & $\times$ & -0.11 & 0.03 \\
\hline & & & & & & & & & & & -0.01 & -0.03 \\
\hline & & & & & & & & & & & --- & --- \\
\hline & & & & & & & & & & & --- & --- \\
\hline \multirow[t]{4}{*}{ Oleic acid $(\%)$} & & & & & & & & & & & $x$ & -0.89 \\
\hline & & & & & & & & & & & & -0.94 \\
\hline & & & & & & & & & & & & --- \\
\hline & & & & & & & & & & & & --- \\
\hline
\end{tabular}


(yield per tree, ripening date, fruit fresh weight, flesh moisture, flesh to stone ratio both on fresh and dry weight basis, flesh and fruit oil content on a dry weight basis, and percentage of palmitic, palmitoleic, stearic, oleic and linoleic acids) provided a total of 66 possible combinations. The number of observations in the pair of characters for which the correlation coefficient was calculated was conditioned by the presence of data of this combination in the same seedling. Data from seedlings in which all the characteristics were evaluated in 1996 and 1997 were used to perform principal components analysis (PCA) using the statistical package The Unscrambler (CAMO A/S, Trodheim, Norway).

\section{Results and Discussion}

Phenotypic Correlations. Correlation coefficients obtained for all the combinations of characters showed a high consistency among the years (Table 2) or planting dates (Table 3). Due to the large number of degrees of freedom, any correlation coefficient with an absolute value of only 0.2 to 0.3 could be significant. Correlation coefficients greater than 0.71 or smaller than -0.71 have been suggested to be biologically meaningful (Skinner et al., 1999), as $>50 \%$ of the variation in one trait is predicted by the other. However, this study is less restrictive and lower correlation coefficients have been considered meaningful, especially given the good consistency for the different years and planting dates.

Significant correlation coefficients were obtained among several of the oil yield components analyzed (Tables 2 and 3, Fig. 1): fruit fresh weight, flesh moisture, flesh to stone ratio both on fresh and dry weight basis, flesh and fruit oil content on a dry weight basis. The correlation between fruit weight and flesh to stone ratio indicates that a greater fruit weight implies a proportionally higher increase in flesh than stone weight. Both characters were also slightly correlated with flesh moisture. Similar results were obtained in progenies from the cross 'Leccino' x 'Kalamata' (Fontanazza et al., 1999), two cultivars with very different fruit size, shape and purpose. Fanizza (1982) has also reported high correlation coefficients among fruit measurements (length, diameter and flesh to stone ratio) and suggested that they are different manifestations of the same physiological function. A positive correlation coefficient between flesh oil content and flesh to stone ratio on a dry weight basis was also obtained, and between both and fruit oil content which was indirectly calculated from them. Correlation among fat, reducing sugars and moisture content in olive flesh have been previously reported for different cultivars (Sánchez-Gómez and Fernández-Díez, 1991). The correlations found among some of the oil yield components may also be useful to reduce the number of traits evaluated, as it has been suggested in other breeding programs (Hansche et al., 1972;

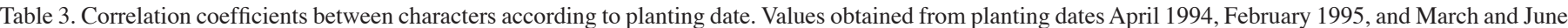
1996 are indicated from top to bottom. Significant correlations at $P<0.01$ are indicated in bold.

\begin{tabular}{|c|c|c|c|c|c|c|c|c|c|c|c|c|}
\hline & $\begin{array}{l}\text { Ripening } \\
\text { date } \\
\text { (d.a.1 Sept.) }\end{array}$ & $\begin{array}{l}\text { Fruit } \\
\text { fresh } \\
\text { wt }(g)\end{array}$ & $\begin{array}{c}\text { Flesh } \\
\text { moisture } \\
(\%)\end{array}$ & $\begin{array}{c}\text { Flesh to } \\
\text { stone ratio } \\
\text { (fresh wt basis }\end{array}$ & $\begin{array}{l}\text { Flesh to } \\
\text { stone ratio } \\
\text { (dry wt basis }\end{array}$ & $\begin{array}{l}\text { Oil content } \\
\text { [flesh dry wt } \\
\text { s)basis }(\%) \text { ] }\end{array}$ & $\begin{array}{l}\text { Oil content } \\
\text { [fruit dry wt } \\
\text { basis }(\%) \text { ] }\end{array}$ & $\begin{array}{c}\text { Palmitic } \\
\text { acid } \\
(\%)\end{array}$ & $\begin{array}{c}\text { Palmitoleic } \\
\text { acid } \\
(\%)\end{array}$ & $\begin{array}{c}\text { Stearic } \\
\text { acid } \\
(\%)\end{array}$ & $\begin{array}{l}\text { Oleic } \\
\text { acid } \\
(\%)\end{array}$ & $\begin{array}{l}\text { Linoleic } \\
\text { acid } \\
(\%)\end{array}$ \\
\hline \multirow[t]{3}{*}{ Yield per tree $(\mathrm{kg})$} & 0.21 & -0.49 & -0.30 & -0.44 & -0.23 & -0.30 & -0.31 & -0.05 & -0.02 & -0.10 & 0.07 & -0.05 \\
\hline & 0.37 & -0.45 & -0.36 & -0.43 & -0.17 & -0.07 & -0.15 & 0.22 & 0.19 & -0.22 & -0.10 & 0.06 \\
\hline & 0.38 & -0.35 & -0.21 & -0.21 & -0.09 & -0.02 & -0.06 & 0.09 & 0.02 & 0.28 & 0.04 & -0.08 \\
\hline \multirow[t]{3}{*}{ Ripening date (d.a.1 Sept.) } & $x$ & -0.32 & -0.50 & -0.35 & 0.06 & 0.22 & 0.16 & -0.43 & -0.26 & 0.01 & 0.44 & -0.38 \\
\hline & & -0.36 & -0.62 & -0.31 & 0.17 & 0.20 & 0.22 & -0.31 & -0.29 & -0.03 & 0.32 & -0.27 \\
\hline & & -0.36 & -0.55 & -0.28 & 0.13 & 0.20 & 0.20 & -0.07 & 0.03 & -0.39 & 0.32 & -0.39 \\
\hline \multirow{3}{*}{\multicolumn{2}{|c|}{ Fruit fresh weight (g) }} & $x$ & 0.53 & 0.67 & 0.28 & 0.22 & 0.28 & 0.30 & 0.13 & -0.03 & -0.31 & 0.31 \\
\hline & & & 0.51 & 0.63 & 0.22 & 0.06 & 0.17 & 0.11 & 0.12 & 0.31 & -0.17 & 0.15 \\
\hline & & & 0.51 & 0.59 & 0.25 & -0.03 & 0.11 & --- & --- & --- & --- & --- \\
\hline \multirow{3}{*}{\multicolumn{2}{|c|}{ Flesh moisture (\%) }} & & $x$ & 0.62 & -0.22 & -0.23 & -0.25 & 0.35 & 0.37 & -0.05 & -0.36 & 0.26 \\
\hline & & & & 0.47 & -0.33 & -0.40 & -0.42 & 0.38 & 0.34 & -0.24 & -0.36 & 0.24 \\
\hline & & & & 0.59 & -0.18 & -0.45 & -0.40 & --- & --- & --- & --- & --- \\
\hline \multirow{3}{*}{\multicolumn{2}{|c|}{ Flesh to stone ratio (fresh weight basis) }} & & & $x$ & 0.57 & 0.28 & 0.46 & 0.28 & 0.05 & -0.05 & -0.28 & 0.31 \\
\hline & & & & & 0.63 & 0.17 & 0.45 & 0.02 & 0.02 & 0.05 & -0.01 & 0.01 \\
\hline & & & & & 0.63 & -0.07 & 0.29 & --- & --- & --- & --- & --- \\
\hline \multirow{3}{*}{\multicolumn{2}{|c|}{ Flesh to stone ratio (dry weight basis) }} & & & & $x$ & 0.63 & 0.88 & -0.02 & -0.23 & -0.03 & 0.03 & 0.05 \\
\hline & & & & & & 0.54 & 0.85 & -0.28 & -0.26 & 0.26 & 0.27 & -0.17 \\
\hline & & & & & & 0.36 & 0.79 & --- & --- & --- & --- & --- \\
\hline \multirow{3}{*}{\multicolumn{2}{|c|}{ Oil content [flesh dry weight basis $(\%)]$}} & & & & & $\times$ & 0.91 & -0.34 & -0.32 & 0.14 & 0.37 & -0.29 \\
\hline & & & & & & & 0.88 & -0.46 & -0.42 & 0.27 & 0.51 & -0.41 \\
\hline & & & & & & & 0.85 & --- & --- & --- & --- & --- \\
\hline \multirow{3}{*}{\multicolumn{2}{|c|}{ Oil content [fruit dry weight basis $(\%)]$}} & & & & & & $x$ & -0.21 & -0.31 & 0.05 & 0.24 & -0.14 \\
\hline & & & & & & & & -0.42 & -0.39 & 0.28 & 0.45 & -0.34 \\
\hline & & & & & & & & - & --- & --- & --- & --- \\
\hline \multirow[t]{3}{*}{ Palmitic acid $(\%)$} & & & & & & & & $x$ & 0.73 & -0.23 & -0.86 & 0.68 \\
\hline & & & & & & & & & 0.67 & -0.08 & -0.88 & 0.71 \\
\hline & & & & & & & & & 0.72 & 0.01 & -0.75 & 0.60 \\
\hline \multirow[t]{3}{*}{ Palmitoleic acid (\%) } & & & & & & & & & $\times$ & -0.32 & -0.57 & 0.33 \\
\hline & & & & & & & & & & -0.14 & -0.51 & -0.56 \\
\hline & & & & & & & & & & -0.29 & 0.27 & 0.42 \\
\hline \multirow[t]{3}{*}{ Stearic acid (\%) } & & & & & & & & & & $x$ & 0.12 & -0.13 \\
\hline & & & & & & & & & & & -0.01 & -0.07 \\
\hline & & & & & & & & & & & -0.45 & 0.55 \\
\hline \multirow[t]{3}{*}{ Oleic acid (\%) } & & & & & & & & & & & $x$ & -0.94 \\
\hline & & & & & & & & & & & & -0.93 \\
\hline & & & & & & & & & & & & -0.98 \\
\hline
\end{tabular}


Souza et al., 1998; Yao and Mehlenbacher, 2000). For instance, fruit fresh weight and fruit oil content are less laborious to measure than the other oil yield components, which suggests the use of

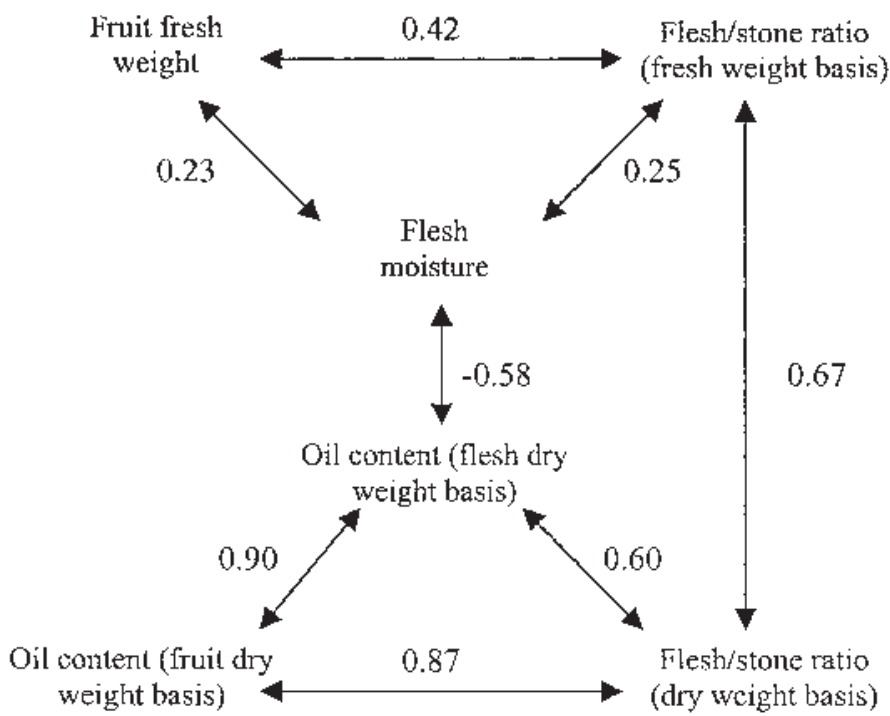

Fig. 1. Correlation coefficients among the oil yield components (averaged over 4 years).

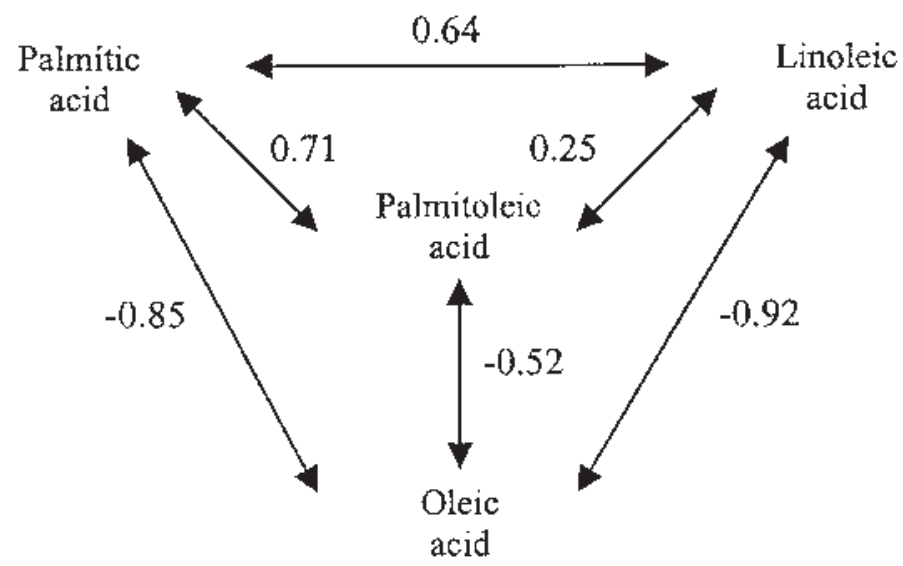

Fig. 2. Correlation coefficients among the fatty acids evaluated (averaged over 2 years). only these traits to enhance the efficiency of an olive breeding program (e.g., with more samples or larger sample size).

A high positive correlation was found among the palmitic, palmitoleic and linoleic acids percentages, especially between palmitic-palmitoleic and palmitic-linoleic (Tables 2 and 3, Fig. 2). This group was negatively correlated with the oleic acid percentage. The negative correlation between oleic and linoleic acids was the highest correlation found among the fatty acids evaluated. These results were highly consistent over the two years evaluated and agree with the correlations reported in olive cultivars collections (Tous and Romero, 1993) or other species such as almond (Abdallah et al., 1998) and hazelnut (García et al., 1994). Studies in soybean mutants, in which a complete inverse relationship between oleic and linoleic acids content was also observed, indicated that mutant alleles may control the linoleic acid content by blocking the synthesis of this acid at the step of oleic acid desaturation (Rahman et al., 1996). A high oleic to linoleic ratio is associated with high stability and low rancidity of olive oil (Tous and Romero, 1993). It also seems to affect, in combination with other minor components, the flavor properties and healthful effect of olive oil (Maestro-Durán and Borja-Padilla, 1990). This high correlation among the different fatty acids may allow simplification of the fatty acids determination and shorten the time needed for the gas chromatography analysis.

A certain correlation of yield with fruit characteristics and ripening date was observed, particularly during the last 2 years (Table 2). The most productive trees seem to have late ripening time and low fruit weight and flesh to stone ratio. No significant correlation was found between yield and fatty acids composition. Similar findings were also reported in almond (Abdallah et al., 1998).

Ripening date was slightly negatively correlated with fruit weight, flesh moisture and flesh to stone ratio (fresh weight basis) for the last two years (Table 2). These correlations may be due to a higher water loss in late ripening trees. The opposite effect was found in other species like almond with a slight tendency for late maturing trees to produce larger fruit (Dicenta and García, 1992). A slight positive correlation between ripening date and oil content was also observed (Tables 2 and 3). Oil accumulation exhibits a sigmoidal pattern with time (Frías et al., 1991; Tombesi, 1990): a first stage shows slow oil biosynthesis until stone hardening, a second phase shows accelerated oil biosynthesis and a final stationary phase corresponding to mature fruit in which the amount

Table 4.- Vector loadings and variation explained by the first three principal components corresponding to 1996 and 1997 data. Main relationships are indicated in bold.

\begin{tabular}{|c|c|c|c|c|c|c|}
\hline & \multicolumn{3}{|c|}{1996} & \multicolumn{3}{|c|}{1997} \\
\hline & PC1 & PC2 & PC3 & PC1 & PC2 & PC3 \\
\hline Accumulated variation explained & 34.24 & 54.77 & 64.99 & 32.42 & 55.49 & 65.29 \\
\hline Yield per tree (kg) & 0.20 & -0.12 & -0.43 & 0.04 & -0.03 & 0.61 \\
\hline Ripening date (d.a.1 Sep) & 0.29 & -0.19 & -0.12 & 0.17 & -0.30 & 0.01 \\
\hline Fruit fresh weight $(\mathrm{g})$ & -0.32 & -0.18 & 0.36 & 0.02 & 0.24 & -0.39 \\
\hline Flesh moisture $(\%)$ & -0.05 & 0.29 & 0.38 & -0.33 & -0.14 & -0.17 \\
\hline Flesh to stone ratio in fresh weight basis & 0.13 & 0.40 & 0.43 & 0.13 & 0.38 & -0.04 \\
\hline Flesh to stone ratio in dry weight basis & 0.31 & 0.41 & 0.07 & 0.32 & 0.40 & 0.10 \\
\hline Oil content in flesh dry weight basis (\%) & 0.38 & 0.33 & -0.05 & 0.40 & 0.31 & 0.08 \\
\hline Oil content in fruit dry weight basis (\%) & 0.35 & 0.15 & -0.12 & 0.40 & 0.20 & 0.05 \\
\hline Palmitic acid $(\%)$ & -0.34 & 0.31 & -0.15 & -0.34 & 0.33 & 0.13 \\
\hline Palmitoleic acid (\%) & -0.34 & 0.07 & -0.03 & -0.29 & 0.15 & 0.23 \\
\hline Stearic acid $(\%)$ & 0.01 & 0.03 & 0.28 & 0.09 & 0.06 & -0.59 \\
\hline Oleic acid $(\%)$ & 0.33 & -0.36 & 0.29 & 0.35 & -0.36 & 0.01 \\
\hline Linoleic acid $(\%)$ & -0.21 & 0.37 & -0.38 & -0.30 & 0.36 & -0.02 \\
\hline
\end{tabular}




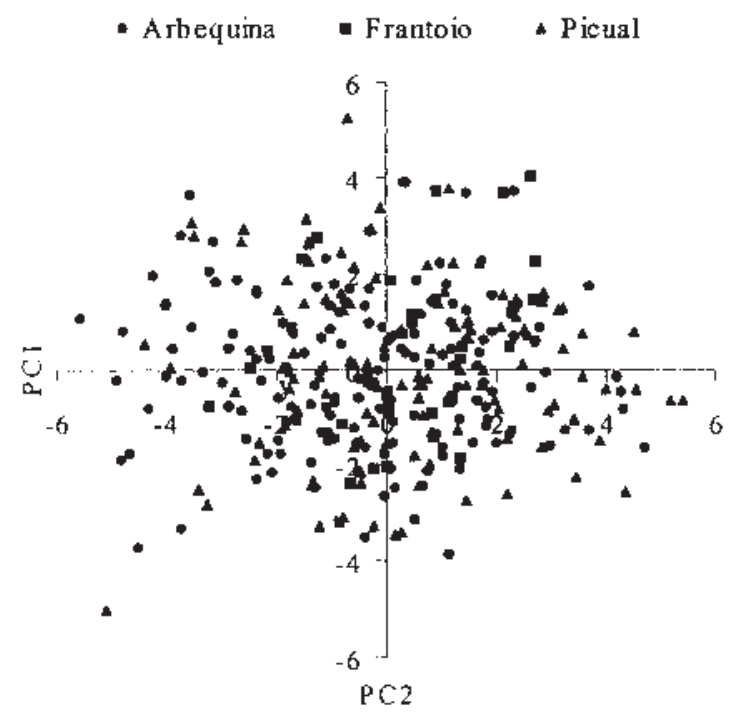

Fig. 3. Projection of the different seedlings in the reduced space determined by the first two principal components according to the female (left) or male (right) parent.

of oil hardly varies. It seems, therefore, that late-ripening plants could have a longer duration of the second phase which could give rise to a greater oil content. Ripening date was only slightly correlated with fatty acid composition (Tables 2 and 3 ). This correlation was negative with palmitic, palmitoleic and linoleic acids and positive with oleic acid. The evolution of fatty acids composition throughout the ripening period of fruit has been studied by several authors without clear conclusions. Thus, while some of them reported a lower oleic acid content throughout the ripening period (Maestro-Durán and Borja-Padilla, 1990; Montedoro and Garofolo, 1984), others indicated the opposite effect (Lavee, 1986; Tombesi et al., 1994). The results obtained in this work indicate that late-ripening seedlings had a slight tendency to accumulate greater amount of oil and incorporate greater proportion of oleic acid (two of the most important objectives of our breeding program). Therefore, selection for these characters could lead to late-ripening cultivars and not to a staggered ripening as would be desirable. However, the existence of early-ripening cultivars with high oil and oleic acid content such as 'Pendolino', 'Uslu' or 'Farga' (Barranco et al., 1998; Del Río and Caballero, 1994; Fontanazza and Patumi, 1994; Tous and Romero, 1993) suggests that the correlation among these characters can be broken.

A slight positive correlation was observed between the oil content and the oleic acid percentage while a negative correlation was observed with palmitic, palmitoleic and linoleic acids (Tables 2 and 3). These results agree with observed correlations among the different fatty acids (Fig. 2). Seedlings with higher oil content thus tended to incorporate more oleic acid than other fatty acids in their triglycerids. A positive correlation between total lipid content and the proportion of stearic and oleic acids and a negative correlation with palmitic, linoleic and linolenic acids has been reported in other species (Zhou et al., 1998).

Principal Components analysis (PCA). PCA was performed with data from 1996 and 1997 with similar results obtained in both years (Table 4). The variance explained by the first three principal components was $34.2 \%, 20.6 \%$, and $10.2 \%$ in 1996 and $32.4 \%, 23.1 \%$, and $9.8 \%$ in 1997 , so that they accumulate $65.0 \%$ and $65.3 \%$ of the total variance, respectively. The first component was positively determined by oil content and oleic acid percent-
- Arbequina - Frantoio a Picual

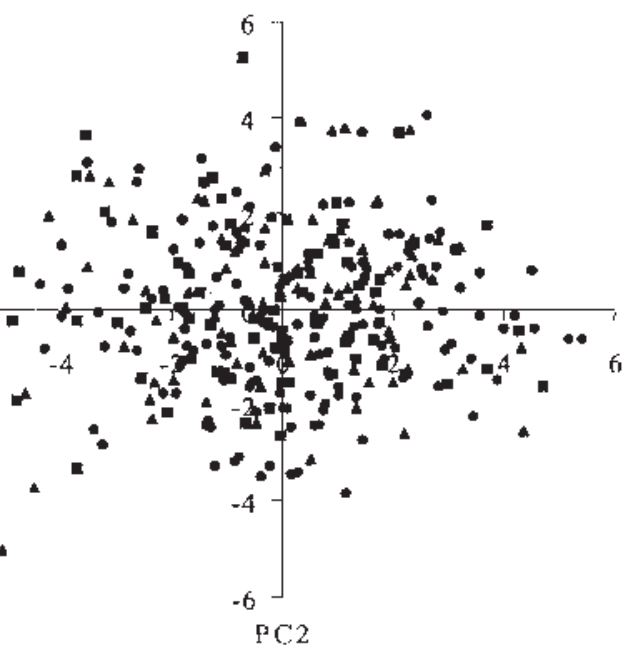

age and negatively by palmitic, palmitoleic and linoleic acids percentage. This component thus reflects the relations among oil yield components and fatty acids composition presented in Figs. 1 and 2 . The second component was mainly positively associated with flesh to stone ratio (both in fresh and dry weight basis) and oil content. It also reflects the negative relation between oleic and linoleic acid. The third principal component was mainly associated to the negative relationship between yield and fruit weight, and consequently to flesh moisture and flesh to stone ratio. It also reflects a positive relationship between stearic acid percentage and fruit fresh weight.

Figure 3 shows a projection of the different seedlings in the reduced space determined by the first two principal components. No association of seedlings according to the female or male parent was found. All seedlings were distributed randomly, indicating that the variability was independent of the parent used.

In summary, significant correlations have been observed among the 66 possible combinations for the 13 characters evaluated, especially among oil yield components, fatty acids composition and, to a certain extent, ripening date. The most relevant correlations were found between oil content and oleic acid percentage, which was negatively correlated as well with palmitic, palmitoleic and linoleic acids percentage. PCA confirmed these correlations and showed that these trends were not affected by the choice of parent used in the crosses. Results are presently being employed to simplify the measurements of these characters and so improve the efficiency of the breeding program.

\section{Literature Cited}

Abdallah, A., M.H. Ahumada, and T.M. Gradziel. 1998. Oil content and fatty acid composition of almond kernels from different genotypes and California production regions. J. Amer. Soc. Hort. Sci. 123: 1029-1033.

Barranco, D., C. de Toro, and L. Rallo. 1998. Epocas de maduración de cultivares de olivo en Córdoba. Invest. Agrar.: Prod. Prot. Veg. 13: 359-368.

Del Río, C. and J.M. Caballero. 1994. Preliminary agronomical characterization of 131 cultivars introduced in the olive germplasm bank of Cordoba in March 1987. Acta Hort. 356:110-115.

Del Río, C. and A.M. Romero. 1999. Whole, unmilled olives can be used to determine their oil content by nuclear magnetic resonance. HortTechnology 9:675-680.

Dicenta, F. and J.E. García. 1992. Phenotypical correlations among some traits in almond. J. Genet. Breed. 46:241-246.

Fanizza, G. 1982. Genetic variability and fruit character associations in 
table olives (Olea europaea). Riv. Ortoflorofrutt. It. 66:115-120.

Fontanazza, G. and M. Patumi. 1994. Influence of cultivars on the composition and quality of olive oil. Acta Hort. 356:358-361.

Fontanazza, G., G. Vergari, M. Patumi, and G. Giorio. 1999. Preliminary results of the evaluation of yield components in an $F_{1}$ segregant population of olive seedlings from the cross Leccino $x$ Kalamata. Acta Hort. 474:97-101.

Frías, L., A. Garcia-Ortiz, M. Hermoso, A. Jimenez, M.P. Llavero Del Pozo, J. Morales, T. Ruano, and M. Uceda. 1991. Analistas de laboratorio de almazara. Informaciones Técnicas, 6/91. Junta de Andalucía. Sevilla, Spain.

Garcés, R. and M. Mancha. 1993. One-step lipid extraction and fatty acid methyl esters preparation from fresh plant tissues. Anal. Biochem. 211:139-143.

García, J.M., I.T. Agar, and J. Streif. 1994. Lipids characteristics of kernels from different hazelnut varieties. J. Agr. For. 18:199-202.

Hansche, P.E., V. Beres, and H.I. Forde. 1972. Estimates of quantitative genetic properties of walnut and their implications for cultivar improvement. J. Amer. Soc. Hort. Sci. 97:279-285.

Lavee, S. 1986. Olive, p. 261-276. In: S.P. Monselise (ed.). Handbook of fruit set and development. CRC Press, Boca Raton, Fla.

Lavee, S., N. Avidan, A. Haskal, and A. Ogrodovich. 1996. Juvenility period reduction in olive seedlings: A tool for enhancement of breeding. Olivae 60:33-41.

Maestro-Durán, R. and R. Borja-Padilla. 1990. La calidad del aceite de oliva en relación con la composición y maduración de la aceituna. Grasas y Aceites 41:171-178.

Montedoro, G. and L. Garofolo. 1984. Caratteristiche qualitative degli oli vergini di oliva. Influenza di alcune variabili: varietà, ambiente, conservazione, estrazione, condizionamento del prodotto finito. Riv. Ital. Sostanze Grasse 61:157-168.

Rahman, S.M., Y. Takagi, and T. Kinoshita. 1996. Genetic control of high oleic acid content in the seed oil of two soybean mutants. Crop Sci. 36:1125-1128.
Sánchez-Gómez,A.H. and M.J.Fernández-Díez. 1991.Correlación entre materia grasa, azúcares reductores y humedad en la pulpa de aceitunas. Grasas y Aceites 42:414-419.

Santos-Antunes, A.F., A. Mohedo, I. Trujillo, and L. Rallo. 1999. Influence of the genitors on the flowering of olive seedlings under forced growth. Acta Hort. 474:103-105.

Scossirolli, R.E., A. Ferrari, and G. Haussmann. 1963. Genetic variability for quantitative characters in alfalfa, p. 597-607. In: W.D. Hanson and H.F. Robinson (eds.). Statistical genetics and plant breeding. Natl. Acad. Sci.-Natl. Res. Council, Wash., D.C.

Skinner, D.Z., G.R. Bauchan, G. Auricht, and S. Hughes. 1999. Amethod for the efficient management and utilization of large germplasm collections. Crop Sci. 39:1237-1242.

Souza, V.A.B., D.H. Byrne, and J.F. Taylor. 1998. Heritability, genetic and phenotypic correlations, and predicted selection response of quantitative traits in peach: I. An analysis of several fruit traits. J. Amer. Soc. Hort. Sci. 123:604-611.

Tombesi, A. 1990. Physiological and mechanical advances in olive harvesting. Acta Hort. 286:399-412.

Tombesi, A., M. Pilli, M. Boco, and P. Proietti. 1994. Evolution of olive fruit respiration, photosynthesis and oil composition during ripening. Acta Hort. 356:278-283.

Tous, J. and A. Romero. 1993. Variedades de olivo. Fundación “La Caixa", Barcelona, Spain.

Visser, T. 1976. A comparison of apple and pear seedlings with reference to the juvenile period. Acta Hort. 56:215-224.

Yao, Q. and S.A. Mehlenbacher. 2000. Heritability, variance components and correlation of morphological and phenological traits in hazelnut. Plant Breed. 119:369-381.

Zhou, M.X., M.G. Holmes, K. Robards, and S. Helliwell. 1998. Fatty acid composition of lipids of Australian oats. J. Cereal Sci. 28:311-319.

Zimmermann, R.H. 1977. Relation of pear seedling size to length of the juvenile period. J. Amer. Soc. Hort. Sci. 102:443-447. 